كاربرد سيستم تالاب مصنوعى با جريان زيرسطحى در تصفيه فاضلاب شهرى در اقليم سرد و خشك (مطالعه موردى تصفيه خانه فاضلاب شهر اراى)

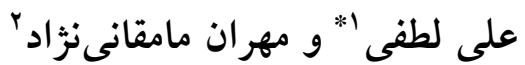

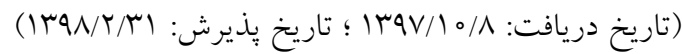

جكيده

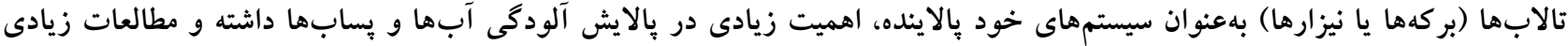

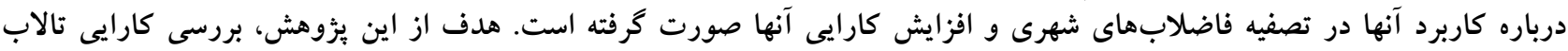

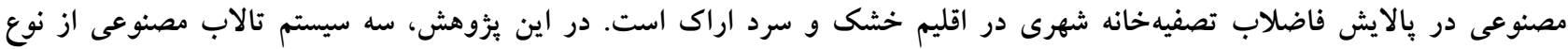

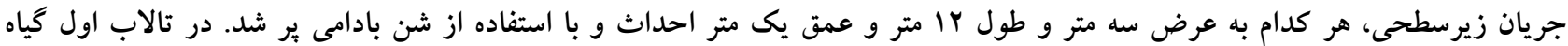

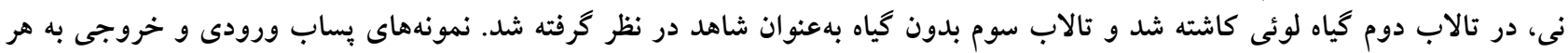

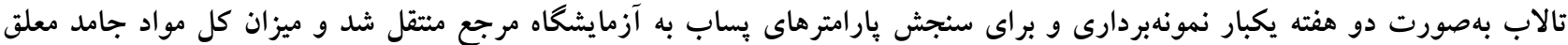

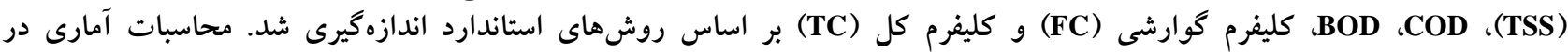
نرمافزار Excel و همجنين با استفاده از نرمافزار SPSS صورت كرفت GC و FOD به TC

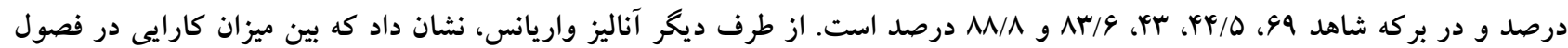

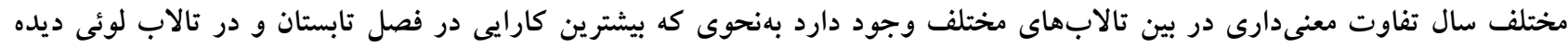

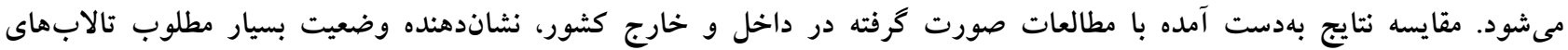

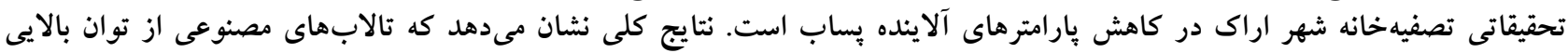

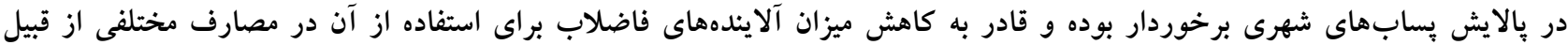

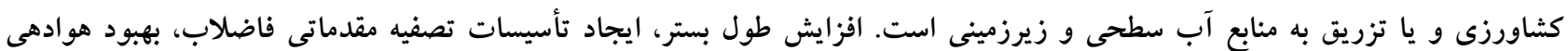

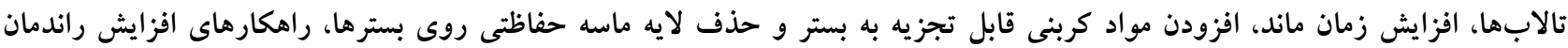

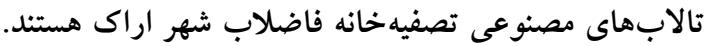

وازههاى كليدى: فاضلاب شهرى، تالاب مصنوعى، تصفيهخانه فاضلاب شهر اراك، گياه نى، گياه لوئى

1. گروه محيط زيست، دانشكده منابع طبيعى، دانشكاه صنعتى اصفهان، ايران

r. دفتر بهبود بهرهورى و تحقيقات شركت آب و فاضلاب استان مركزى، ايران *otfi@iut.ac.ir :مسئول مكاتبات 
جزء زنـــه ايسن سيسـتم تشـكيل مى دهنـــ (با). فراينـدهاى

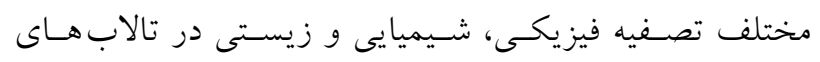

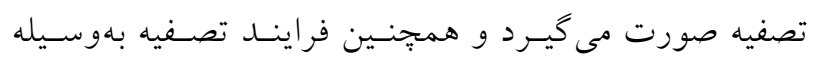

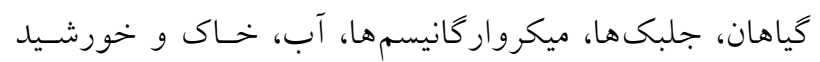
تشديد و تقويت مىشود. مهمترين مكانيسم حذف آلايندهها در

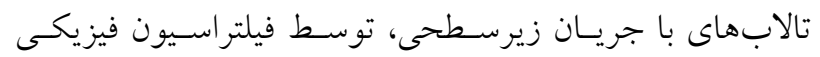

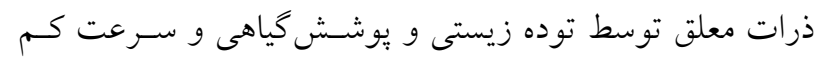

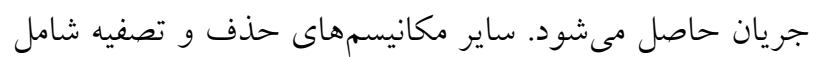
ترسيب شيميايى و جذب مواد مغذى مثل فسفر بهوسيله خـاك،

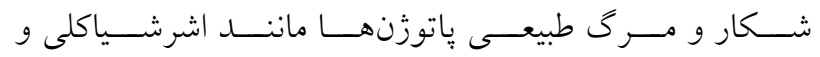
كرييتوسسبوريديوم توسط افـزايش تنـوع و تـراكم شـكارجيان

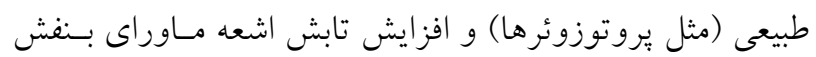

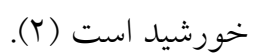
اهميت استفاده از تالابهاى مصنوعى، در كاهش هزينهها از

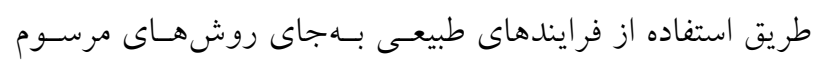

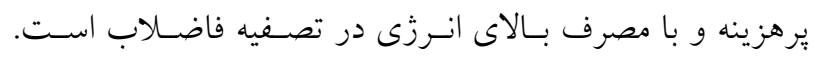

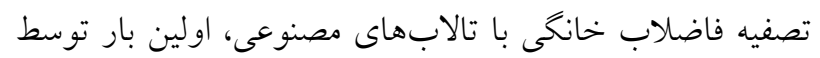

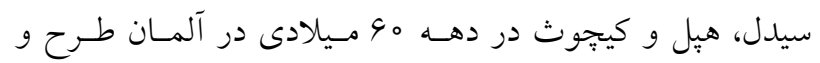

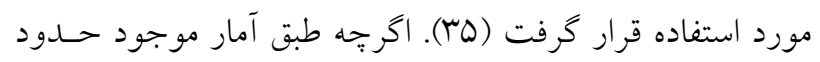

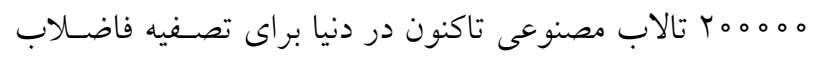

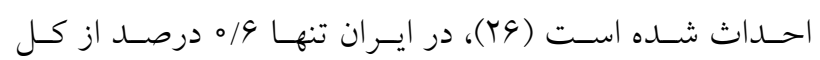
سيستمهاى تصفيه فعال كشور براى تصفيه فاضلابهاى شهرى نهر از اين نوع است (YY).

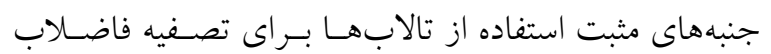
عبارتاند از: عملكرد ساده، هزينه بايين ساخت تأسيسات، بهدام

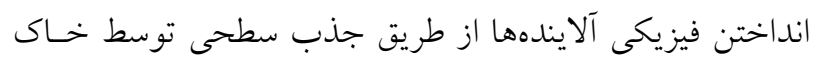

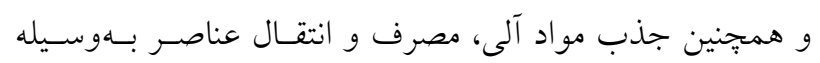

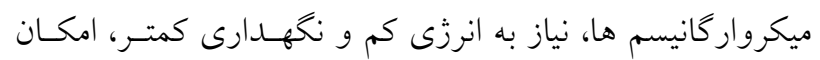

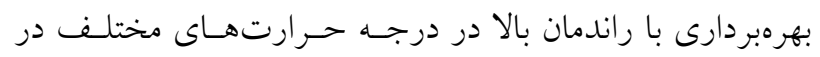

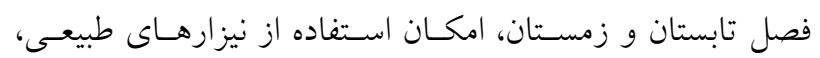
انتخاب محل تصفيه خانه دور از مناطق مسكونى، عـدم توليـد

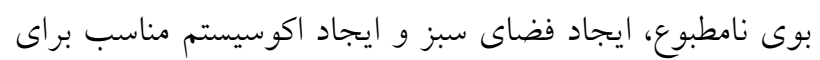

مقدمه

يسـابها و فاضـلاب هاى شـهرى و غيرشـهرى (كشــاورزى، صنعتى و ...) از عمدهترين مشكلات محيط زيستى شهرنشـينى در دنياى امروزى هستند كه عـدم جمـع آورى و تصـفيه و دفـع نامناسب آنها باعث بروز آلودگى محيط زيست از قبيل آلـودگى منابع آب سطحى و زيرزمينى، آلودكى خاكهـا، انتشـار عوامـل بيمارىزا و ميكرببهـا، انتشـار بـوى نـامطبوع و ... مىشـود. از طرف ديخـــ عـدم تصـفيه صـحيح فاضـالابها، مىتوانــ منبـع ارزشمندى از آب را كه قابليت تأمين بسيارى از نيازهاى جوامع امروزى از قبيل كشاورزى و فضاى سبز را دارد را تلف سـاخته و از دسترس خارج سازد (Y)). امروزه روشها و فر ايندهاى مختلـف فيزيكى، شـيميايى و

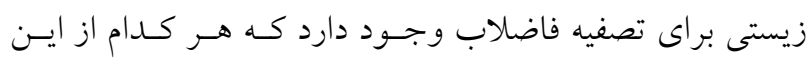
روشها، مزايا و محدوديتهاى خاص خود را دارد و استفاده از

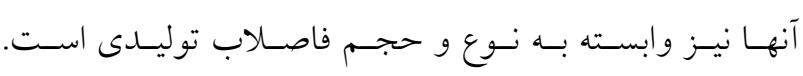
تالابهاى مصنوعى (Constructed Wetland، بركهها يا نيزارهـاى مصسنوعى) سيسـتمهاى تـالابى مهندسـى شــده هسـتند كـهـ از

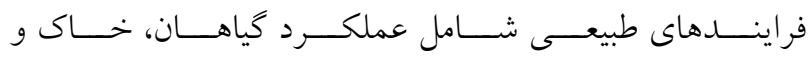
ميكرواركانيسمها، در تصفيه يُاب استفاده مى كند. از تالابهاى مصنوعى علاوه بر تصفيه فاضلاب شهرى، مىتوان براى تصـفيه

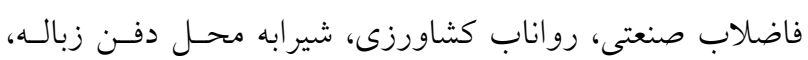
زلالسازى و تصفيه بيشرفته بِاب، احياى درياجِههاى مغذى شده Eutrophic lake) نظيسر فسـفر و نيتـرات و همجزنسين دنيفريفيكاسـيون بِــابها استفاده كرد (10) (1). تالاب هاى مصنوعى از حدود ينج دهـ قبل بهعنوان جزئى

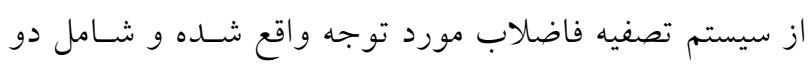
دسته تالاب هاى جريان سـطحى بـا سـطح آزاد آب يـا FWS SSF و تالابهــاى زيرسـطـى يــا (Free Water Surface) با جريان عمـودى رو بـه بـالا و جريـان (Sub Surface Flow) افقى مىشوند. تالابهاى مصنوعى از شن، ماسـه و سـاير مـو اد متخلخل برشده كه بستر مناسبى را براى رشد گياهـان بـهنعنوان 


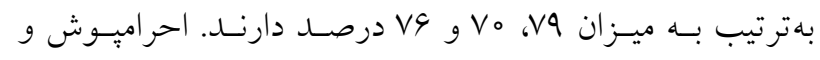

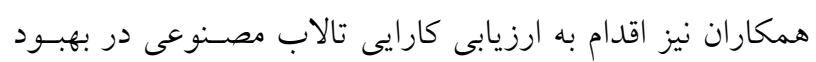

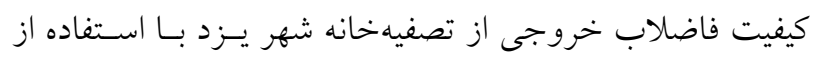

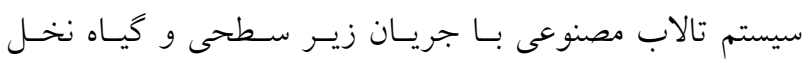

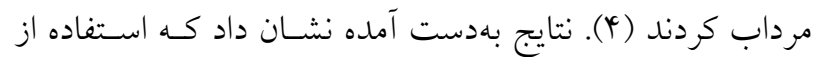

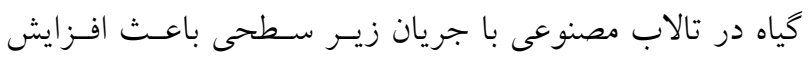

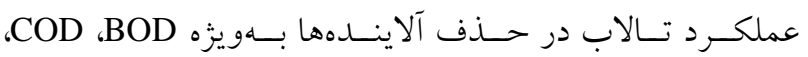
جامدات معلق، كليفرم كل و كليفرم گوارشى بهترتيب به ميـزان 

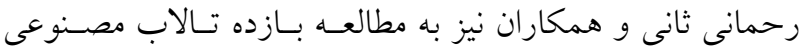

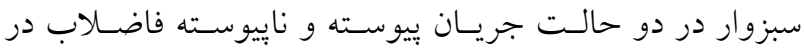

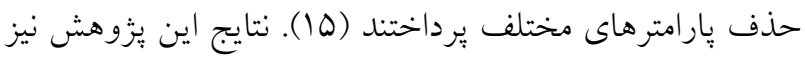
نشان داد كه تالاب مصنوعى صرف نظر از نوع جريان، از بـازده

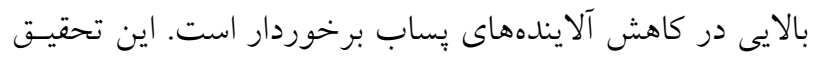

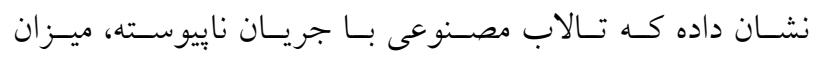

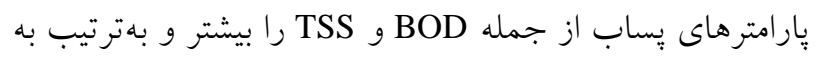
ميزان كو و QV دوصد در مقايسه با رانـدمان تـالاب بـا جريـان

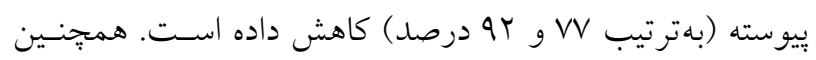

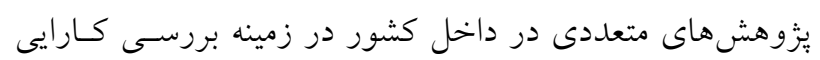

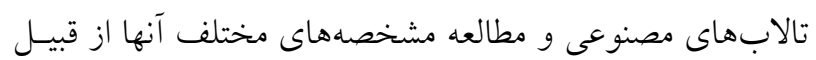

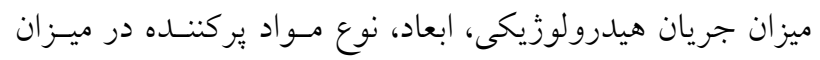

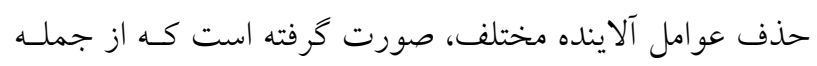

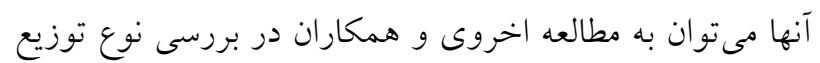
جريان پِاب و رفتار هيدروليكى تالاب (ب إ) اشاره كرد. در خارج از كشور نيز مطالعات كستردهاى در زمينه كـاربرد

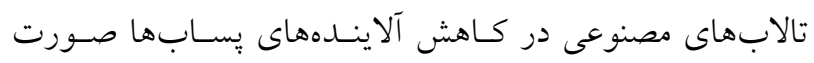

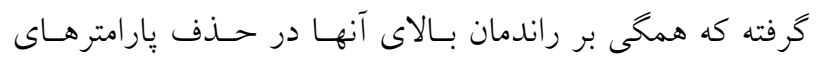

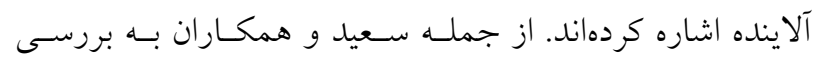

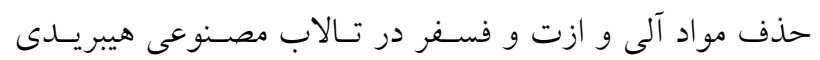

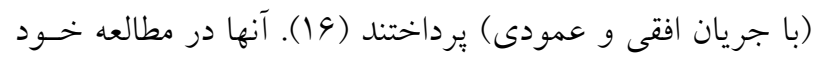

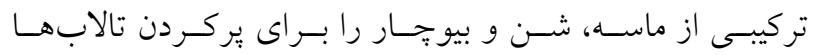

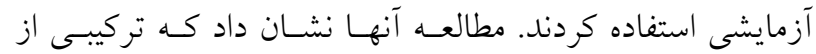

جذب و نخهدارى از حيات وحسش و در نتيجـه ارتقـاى تنسوع

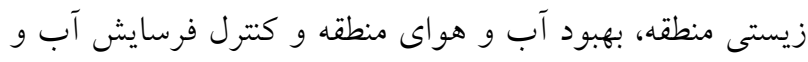
باد اشاره كرد (19). از طرف ديخر اين سيستمها در عين داشتن

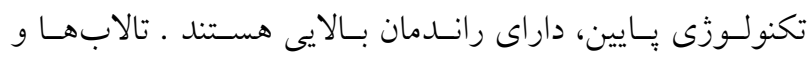

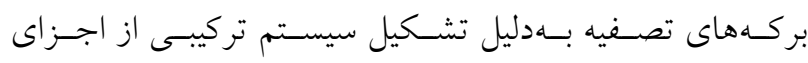

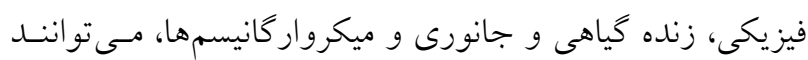

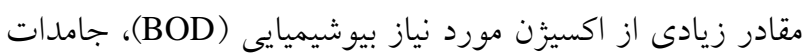
معلـق (SS)، مــو اد مغـــى از قبيـل نيتــروزن و فسـفر (P,N)،

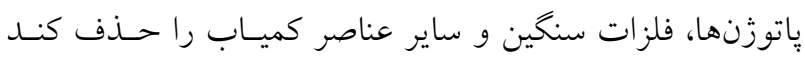

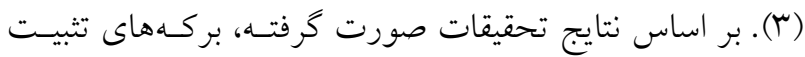

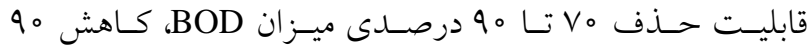
درصـــى COD، كــاهش VD درصسـدى TSS، كــاهش 99

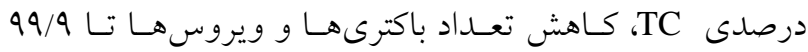

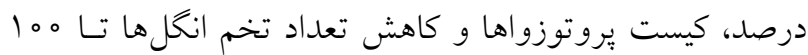
درصد را دارد (ه).

در زمينه بررسى كـارايى تالابهـاى مصـنوعى در تصـفيه

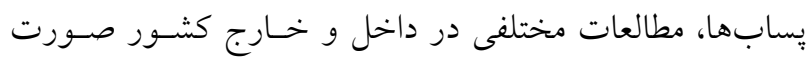

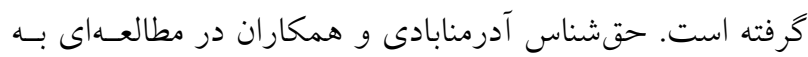

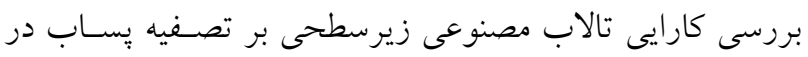

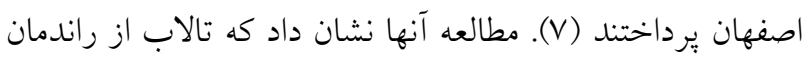

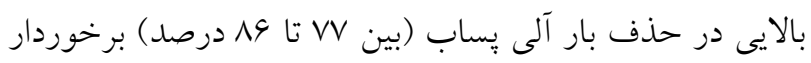

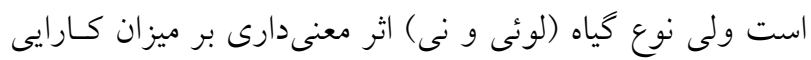
آن ندارد. در مطالعه ديخرى اسلامى و همكاران كـارايى تـالاب مصنوعى زيرسطحى در حـذف ميـزان BOD، COD و TSS در مقايسه با بركه تثبيـت را مـورد تحقيـق قـر ار دادنـــ (ه). نتـايج حاصل از اين بززوهش نشان داد كه تالاب مصسنوعى از رانــمان بالاترى در حذف يارامترهاى ذكر شده برخوردار بوده و بنابراين

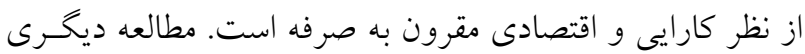

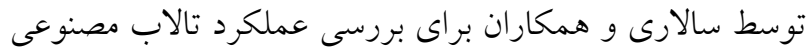

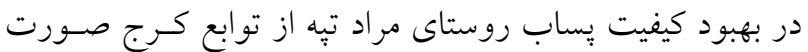

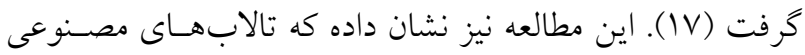

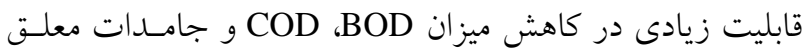




\section{طراحى و احداث تالابهاى مصنوعى} سه سيستم تالاب مصنوعى از نوع سيستم زيرسطحى به ابعاد

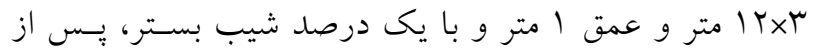
حفــر زمسين و عايق سـازى اسـتخر بــا اسـتفاده از ورقـههاى

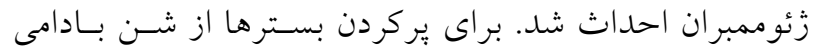

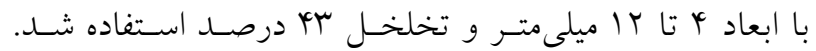
همجينين براى ايجاد سازه توزيع كننده و خارج كنــده يسـاب در ابتدا و انتهاى هر بستر (به عـرض م^ سـانتىمتر) از قلوهسـنى

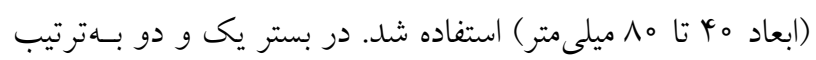
كياه لوئى (Typha latifolia) و كياه نـى (Phragmites australis) از سطح منطقه جمع آورى و به فاصـله of سـانتى متر از همــيخر و در

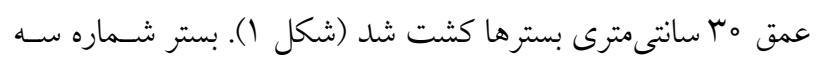

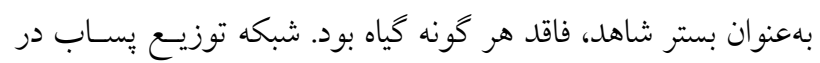

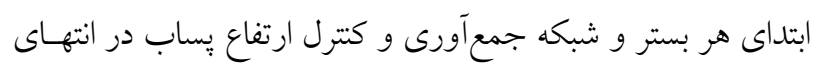
بسترها طراحى و نصب شـد. بِّـاب خروجسى از بركههاى تثيـت تصفيهخانه اراك، به ميزان ه/ا ليتر در دقيقه وارد هر تالاب شد.

نمونهبردارى، آزمايشها و محاسبات آمارى يس از طى شدن جهار هفته بـهمنظـور تثبـت و رشـد مناسـب كياهان كشت شده، نمونههاى يساب از ورودى و خروجى هـ هـر تالاب بهصورت دو هفته يكبار در ظـروف يـك ليتـرى تهيـه و بلافاصله به آزمايشـخاه معتمــ شـركت آب و فاضـلاب اسـتان مركزى در محل تصفيهخانه منتقل شد. بِار امترهاى مورد سنجش

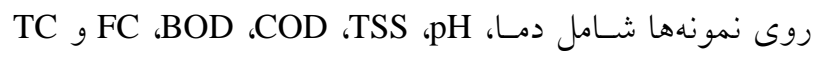
بود كه بر اساس روشهاى استاندارد آزمايشـحاهى (pH مطـابق

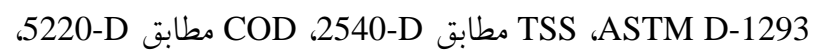
مطابق FOD و FC 5210-B مطابق TC قرار گرفتند (9). دادههاى حاصل با استفاده از نرمافـزار SPSS مـورد

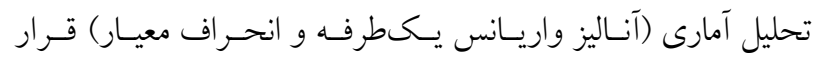

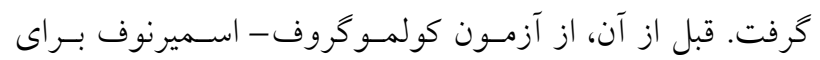
اطمينان يـافتن از نرمـال بــودن توزيـع دادههـا اسـتفاده (Y I) و نمودارهاى مربوطه با استفاده از نرمافزار Excel رسم شد.
تالبهاى افقى و عمودى و استفاده از كربن فعال، باعث كاهش بالاى ه9 درصـدى بـار آلى BOD، م9 درصـدى ازت و و درصدى فسفر شده است. هدف از اين بزظوهش، سـنجش تــوان و كـارايى تالابهــاى

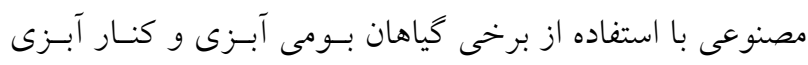
(مانند بوريا، لوئى و ...) در افزايش كارايى تصفيه يساب واحسـ تصفيهخانه شهر اراك است كه بدين منظور اجـراى يـك طـرح

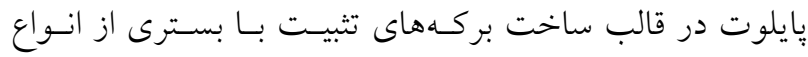

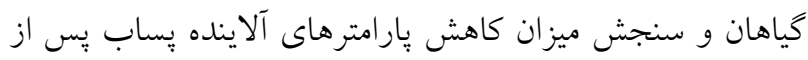
خروج از اين بركهها بيشبينى شده است. يكى از اهداف اصلى

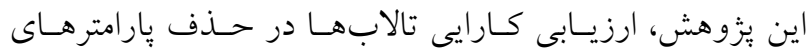
آلاينده يساب تصفيهخانه در فصول سرد سال نسـبت بـه سـاير فصول با توجه به اقليم سرد و نيمهخشك اراك اسـت. بـهدليـل افت كارايى بركههاى تثبيت تصفيهخانه فاضلاب اراك، اسـتفاده از روشى كه قادر به افزايش بازدهى آن در فصـول سـرد باشـد،

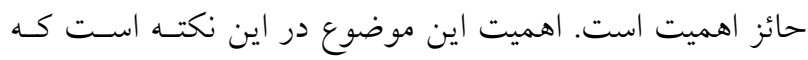

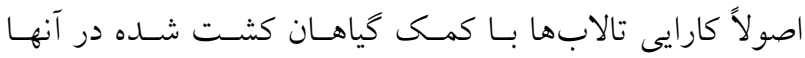
افزايش يافتـه و عــدم فعاليـت گياهـان در فصـول سـرد سـال،

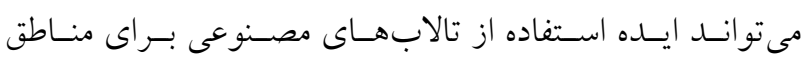
سردسير را با ابهام مواجه سازد.

\section{مواد و روشها} اين يزوهش در تصـفيهخانه فاضـلاب شـهر اراك انجـام شـده است. متوسط ارتفاع منطقه V01 متر بالاتر از سطح دريـا بـوده و منطقه با متوسـط بارنـدگى سـاليانه هبr ميلىمتـر و ميـانكين دماى ساليانه // ا درجه سانتى گراد بر اساس طبقهبندى آمبـرزه داراى اقليم نيمهاخشك و سرد و بر اسـاس طبقهبنــى دمـارتن داراى اقليم نيمهذشك اسـت (9). تصـفيهخانه فاضـلاب شـهر اراك در دو كيلومترى جنوب غربى تالاب واقع شـده و بِّـاب تصفيهخانه به آن تخليه مىشود. بنابراين افزايش كيفيت بِّاب خروجى از تصفيهخانه و رعايـت اسـتانداردهاى موجـود حـائز

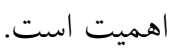




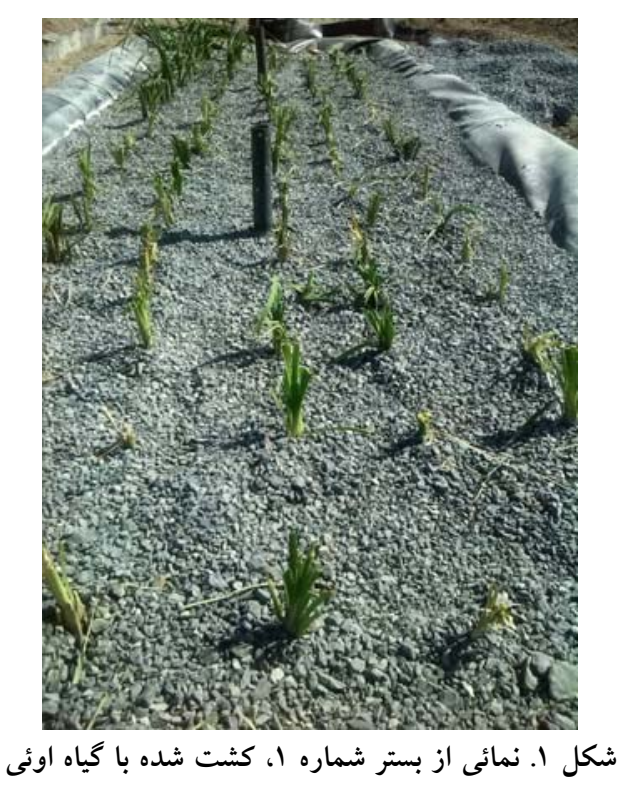

\begin{tabular}{|c|c|c|c|c|}
\hline \multicolumn{3}{|c|}{ خروجى } & \multirow{2}{*}{ ورودى } & \multirow{2}{*}{$\mathrm{pH}$} \\
\hline تالاب شاهل & تالاب نى & تالاب لوئى & & \\
\hline V/9 & $\mathrm{V} / \mathrm{Q}$ & $V / Q$ & $\mathrm{~V} / \mathrm{Q}$ & ميانخين \\
\hline$N / T Y$ & N/N & $\Lambda / \mu l$ & N/OH & حداكثر \\
\hline $\mathrm{V} / \mathrm{IT}^{\mathrm{r}}$ & $9 / 94$ & $9 / 99$ & $\mathrm{~V} / 01$ & حداقل \\
\hline $0 / Y 1$ & $\circ / T V$ & $0 / \mu 1$ & $\circ / Y \Lambda$ & انحر اف معيار \\
\hline
\end{tabular}

\begin{tabular}{|c|c|c|c|c|}
\hline \multicolumn{3}{|c|}{ خروجى } & \multirow{2}{*}{ ورودى } & \multirow{2}{*}{ TSS } \\
\hline تالاب شاهد & تالاب نى & تالاب لوئى & & \\
\hline$r_{0} / r \pm Q / V$ & $r \Lambda / \mu \pm 9 / 1$ & $r Y / 1 \pm 9 / 9$ & $\| \mu \Delta / \circ \pm \psi \mid / \varphi$ & ميانخين و انحراف معيار (mg/L) \\
\hline 99 & vq & VV & 。 & كارايى (درصد حذف) \\
\hline
\end{tabular}

مىدهد كه طى فرايندهاى مختلف در تالابهاى مصنوعى تحت

آزمايش، pH تغييرات زيادى نداشته است (جدول (). در جـــول (Y) ميــزان كـل مــواد جامــــ معلـق (TSS) اندازهيرى شده در ورودى و خروجى تالابها نشان داده شده است. همانطور كه نتايج نشان مىدهد، هر سه تالاب مصسنوعى از ميزان مواد جامد معلق كاستهاند، اگر جهه اخـتلاف معنسى دارى

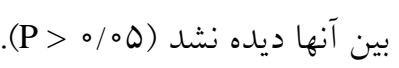

مافته ها

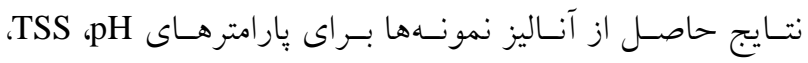
COD ، و كليفرم كل و كوارشى در جدول ( ا تا ه) نشان

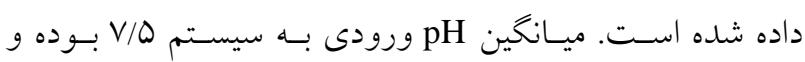
ميانخين خروجى آن براى تالاب لوئى، نـى و شـاهد بـهترتيـب

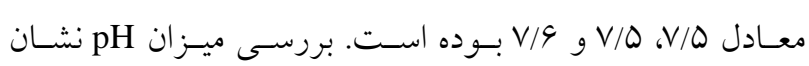


جدول r. نتايج حاصل از آزمايش ميزان BOD در ورودى و خروجى تالابها (بر حسب ميلى گرم بر ليتر) و درصد كارايى هر تالاب

\begin{tabular}{|c|c|c|c|c|}
\hline \multicolumn{3}{|c|}{ 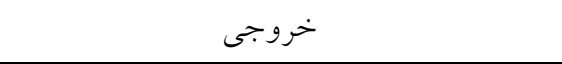 } & \multirow{2}{*}{ 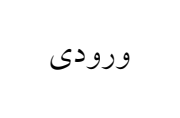 } & \multirow{2}{*}{ BOD } \\
\hline تالاب شاهد & ت تالاب نى & تالاب لوئى & & \\
\hline$r \mu / r \pm I r / r$ & $\varphi \circ / \pi \pm 11 / 9$ & $\Gamma \mathrm{T} / \Lambda \pm \Delta / q$ & $V \varepsilon / \Lambda \pm M / \Lambda$ & ميانگين و انحراف معيار (mg/L) \\
\hline$\kappa \%$ & $Y Q / 9$ & $09 / 1$ & 。 & كارايى (درصد حذف) \\
\hline
\end{tabular}

جدول f. نتايج حاصل از آزمايش ميزان COD در ورودى و خروجى تالابها (بر حسب ميلىگرم بر ليتر) و درصد كارايى هر تالاب

\begin{tabular}{|c|c|c|c|c|}
\hline \multicolumn{3}{|c|}{ خروجى } & \multirow{2}{*}{ 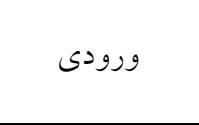 } & \multirow{2}{*}{ COD } \\
\hline تالاب شاهد & ت تالاب نى & تالاب لوئى & & \\
\hline $11 V / \circ \pm T V / 1$ & $11 \% / 9 \pm r r / 9$ & $100 / \mu \pm \mid V / 1$ & $r \circ V / I \pm 99 / 9$ & ميانخين و انحراف معيار (mg/L) \\
\hline$k+/ \mathrm{b}$ & $9 \circ / \mathrm{V}$ & $91 / 4$ & 。 & كارايى (درصد حذف) \\
\hline
\end{tabular}

جدول ه. نتايج حاصل از آزمايش ميزان كليفرم كوارشى در ورودى و خروجى تالابها MPN/1.omL) و درصد كارايى هر تالاب

\begin{tabular}{|c|c|c|c|c|}
\hline \multicolumn{3}{|c|}{ خروجى } & \multirow[t]{2}{*}{ ورودى } & \multirow{2}{*}{ كليفرم كوارشى } \\
\hline تالاب شاهد & تاب نى & تالاب لوئى & & \\
\hline $0 / 1 \Gamma \times 10^{9} \pm 0 / 0 \Delta \times 10^{9}$ & $0 / 10 \times 10^{9} \pm 0 / 0 \Delta \times 10^{9}$ & $0 / \mid r \times 10^{9} \pm 0 / 0 \Delta \times 109$ & $1 / T \Delta \times 10^{9} \pm 0 / \Delta r \times 10^{9}$ & ميانكين و انحراف معيار (mg/L) \\
\hline$\wedge r / 9$ & $\wedge 9 / 1$ & $9 T / 4$ & - & كارايى (درصد حذف) \\
\hline
\end{tabular}

ميانخين حذف 90/V درصد، بيشترين كارايى را نسبت به تـالاب

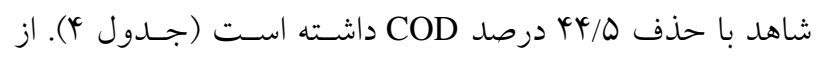
طرف ديخر نتيجه آناليز واريانس تفاوت معنىدارى ميـان ميـزان

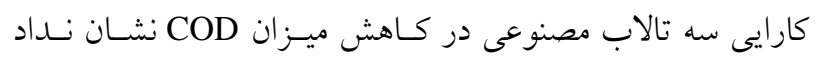

$$
\text { . (P> }>\circ \Delta)
$$

بر اساس نتايج بهدست آمده ميانخين تعداد كليفـرم كوارشسى در ورودى هر سه تالاب

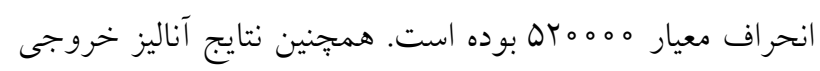

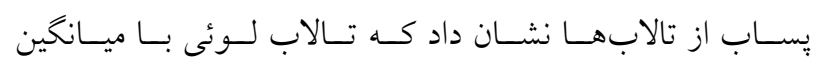

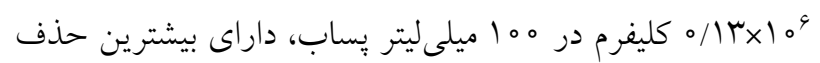

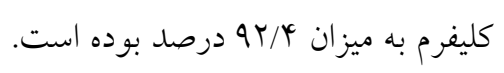

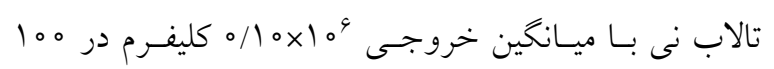

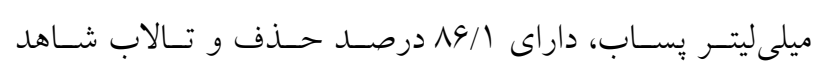

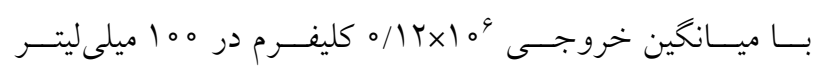

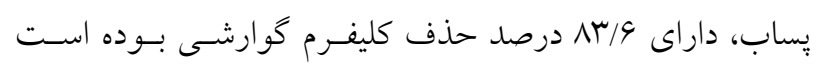

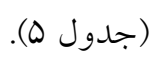

بر اساس نتايج بهدست آمده ميزان BOD ورودى بهطور ميانخين

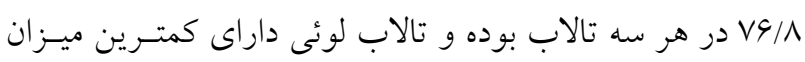

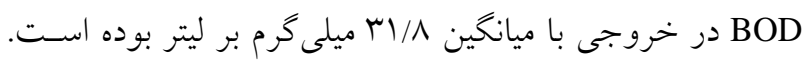

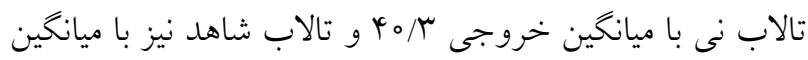

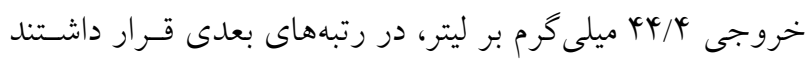

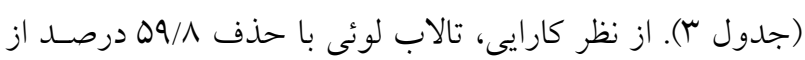

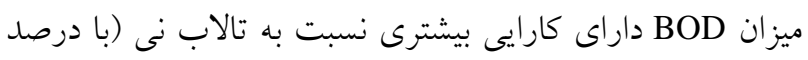

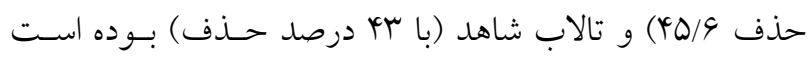

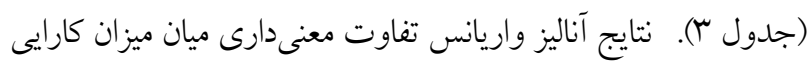

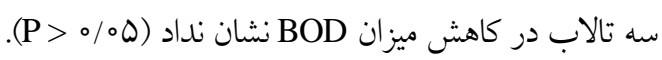

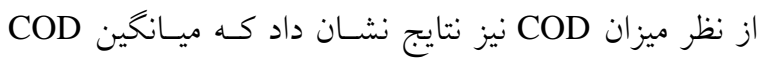

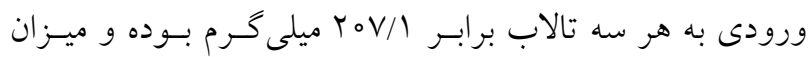
COD COD

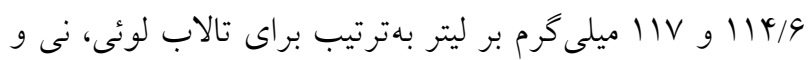

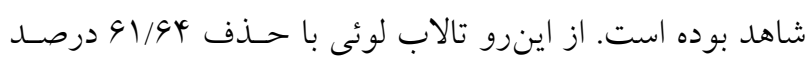

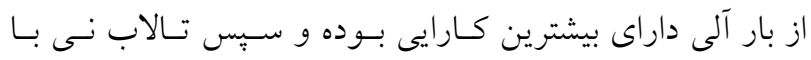




\begin{tabular}{|c|c|c|c|c|}
\hline \multicolumn{3}{|c|}{ خروجى } & \multirow[t]{2}{*}{ ورودى } & \multirow{2}{*}{ كليفرم كل } \\
\hline تالاب شاهد & تالاب نى & تالاب لوئى & & \\
\hline $0 / 1 r \times 10^{9} \pm 0 / 00 \times 10^{9}$ & $0 / 14 \times 10^{9} \pm 0 / 04 \times 10^{9}$ & $0 / 14 \times 10^{9} \pm 0 / 09 \times 109$ & $1 / T V \times 10^{9} \pm 0 / \mu 4 \times 10^{9}$ & ميانكين و انحراف معيار (mg/L) \\
\hline$M / \Lambda$ & $90 / 1$ & $94 / 1$ & - & كارايى (درصد حذف) \\
\hline
\end{tabular}

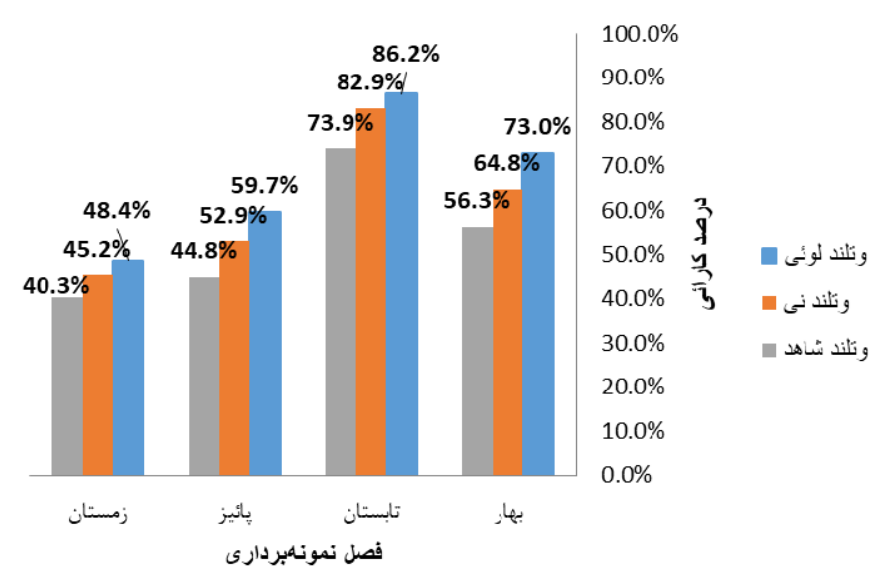

شكل r. تغييرات ميزان كارايى تالابهاى مصنوعى در حذف ميزان BOD در طول زمان

نمودار شكل (Y) نشاندهنــده درصــ حــف BOD در فصـول مختلف توسط تالابهاى طراحى شده است. اين نمودار مشخص مى سازد كه بيشترين كارايى تالابها در حذف BOD در فصل تابستان و كمترين ميزان آن نيز در فصـل زمستان بوده است. تحليل آمـارى نتـايج نشـان مىدهـد كـه در تالاب لوئى اختلاف معنى دارى (هه/。 p p) از نظر ميزان حذف

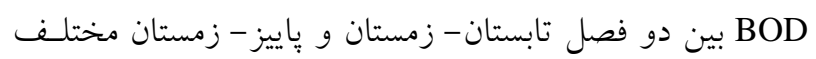
وجود دارد. ميزان حذف BOD در تالاب نى و تالاب شـاهد در فصول مختلف معنى دار نبوده است (P) > P (P). براى بررسى ميزان تأثير فصلى تالابهــا بـر كـاهش ميـزان COD

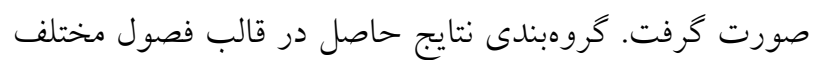
در شكل (r) نشان داده شده است. بهطور كلى كـارايى تـالابهــا در حــف COD در فصـل تابستان بيشتر از همه فصول و در زمستان كمتـرين ميـزان بـوده است. تحليل آمارى نتايج نشان مىدهد كه فقط كـارايى تـالاب

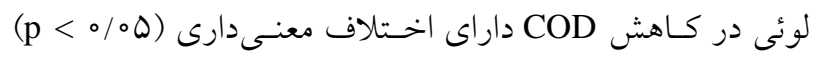

آزمون واريانس يكىطرفه، اختلاف معنى دارى را ميان سه تالاب مصنوعى از نظر ميزان كارايى در كاهش كليفرم گوارشسى نشـان نداد (P> (P) (P) نتيجــه آزمـايش نمونسههاى بِّـاب ورودىى و خروجـى از تالابها براى سنجش ميزان كليفرم كل نشـان داد كـه ميـانكين تعداد كليفرم كل ورودى هر سه تـالاب ه

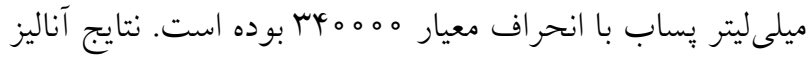

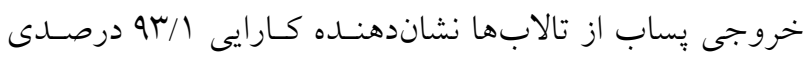

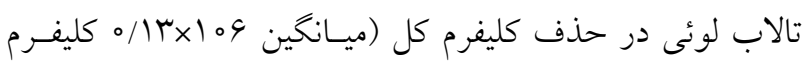
كل در ه ه إميلى ليتر يساب) بوده است. تالاب نـى بـا ميـانكين

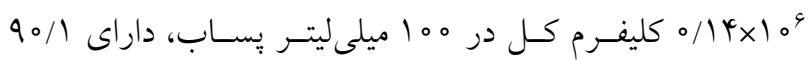
درصد حذف بوده اسـت. تـالاب شـاهد بـا ميـانخين خروجسى لئي

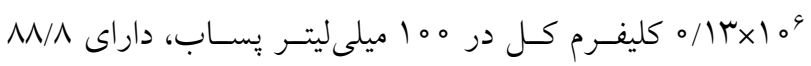
درصد حذف كليفرم كل بوده است (جدول 9). نتيجه آزمون واريانس يكطرفه، اختلاف معنى دارى را ميان سه تالاب مصنوعى از نظر ميزان كارايى در كاهش كليفـرم كـل نشان نداد (P> > (P). 


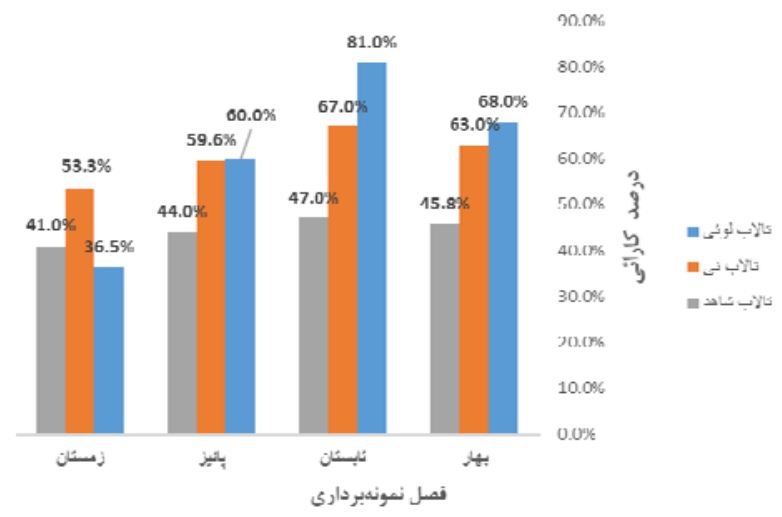

شكل r. تغييرات ميزان كارايى تالابهاى مصنوعى در حذف ميزان COD در طول زمان

\begin{tabular}{|c|c|c|c|}
\hline تالاب شاهد & تالاب نى & تالاب لوئى & يار بامتر \\
\hline r & $Y Q / 9$ & $\Delta Q / \Lambda$ & BOD \\
\hline$\mu \varphi / \Delta$ & $9 \circ / N$ & $91 / 4$ & COD \\
\hline$\wedge r / 9$ & $\wedge 9 / 1$ & $9 T / 4$ & كليفرم كَوارشى \\
\hline$M / \Lambda$ & $90 / 1$ & $9 r / 1$ & كليفرم كل \\
\hline
\end{tabular}

تا ب/ با ميانخين V/D) كـه در مقايسـه بـا استـاندارد كشـورمان

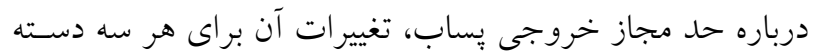

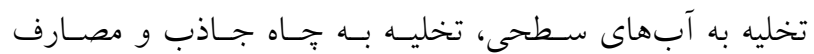

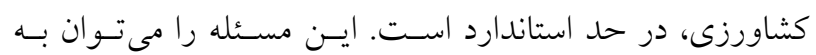
خاصيت بافرى تالابها، ناشسى از جـنس مـواد بستر تـالاب و

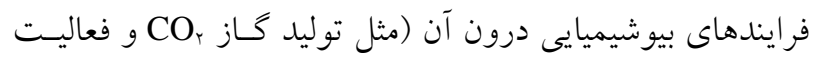

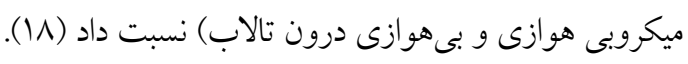

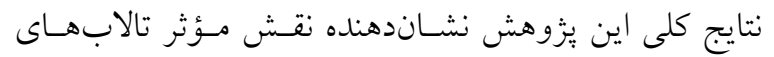
مصنوعى در كاهش ميزان آلايندههاى مختلف است (جدول V V).

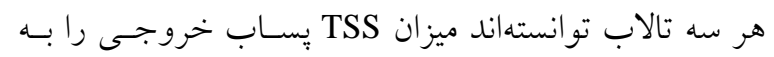

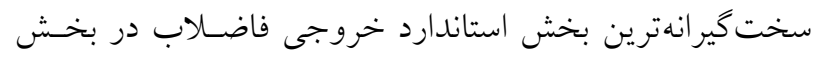

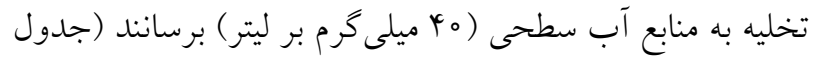
Y). مقايسه نتايج خروجى هر سه تالاب مصسنوعى بـا استاندارد خروجى فاضلاب براى يارامتر BOD نشان مىدهد كـه هـر سـه

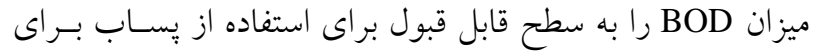

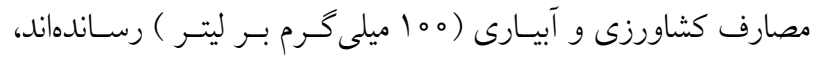

بين دو فصل بهار - زمستان و تابستان- زمسـتان اسـت. ميـزان

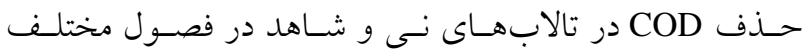

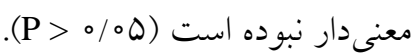

\section{نتايج و بحث}

روش تصفيه يُساب با استفاده از تالابهاى مصـنوعى، از جملـه

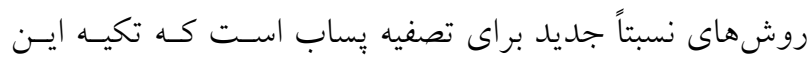

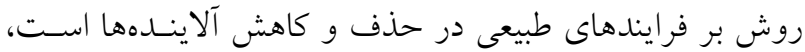

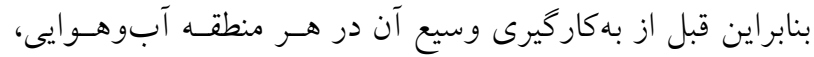
ابتدا بايستى مطالعات مقــماتى در زمينـه سـنجش كـارايى آن و انتخاب گونه مناسب با توجه به منطقه جغر افيايى صورت گيـرد.

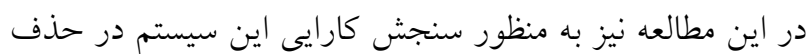

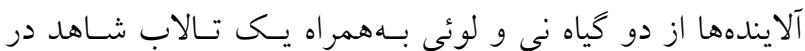
تصفيهخانه فاضلاب شهر اراى استفاده شد. بررسى ميزان pH نشان داد كه اين پيارامتر از دامنـه تغييـرات

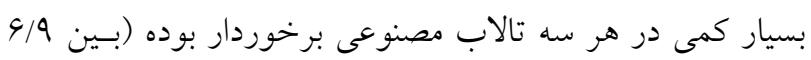




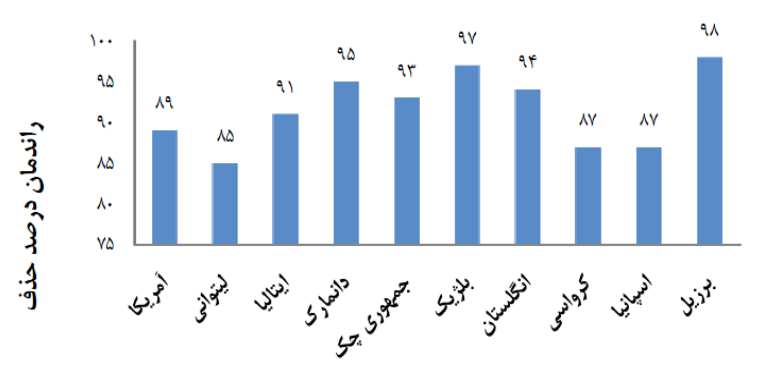

شكل f. نمودار راندمان حذف ميران BOD فاضلاب شهرى توسط تالاب مصنوعى با جريان زيرسطحى (ه)

مصنوعى يزد (9) و تالاب مصنوعى سارى (YN) همخوانى دارد.

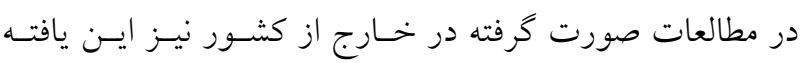

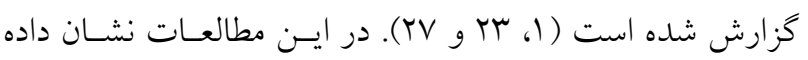

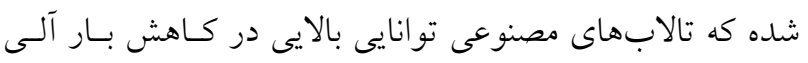

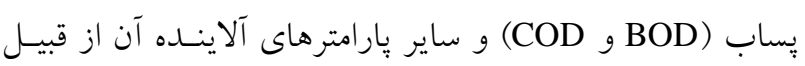

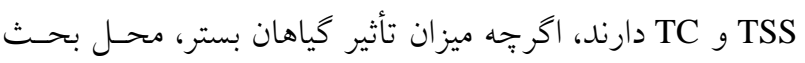

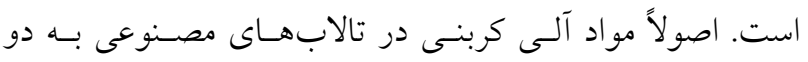
روش هوازى و بىهوازى تجزيه مىشوند. هر دوى اين فرايندها

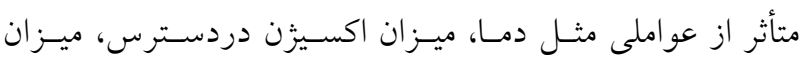
باركذارى و زمان ماند هيدروليكى است (Y9). وجود كياهـان در بستر علاوه بر تشـديد فعاليـت تجزيسه آلاينـدهها بـهدليل

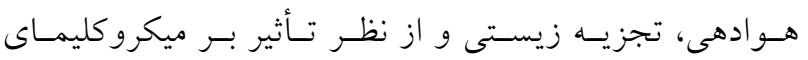
منطقه، ايجاد يك اكوسيستم كوجى مصنوعى، جذب حيـات وحش، ايجاد فرصتى براى تحقيق و آمسوزش دربـاره محسيط زيست و تغيير در سيماى سرزمين و در نتيجه افزايش توجـهـ

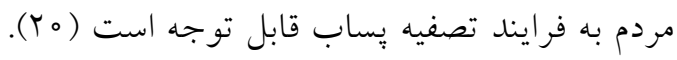
در مطالعـات متعــد صـورت كرفته در خـارج نيـز، نتـايج

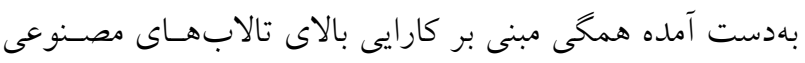

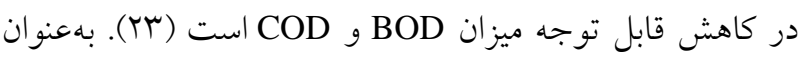

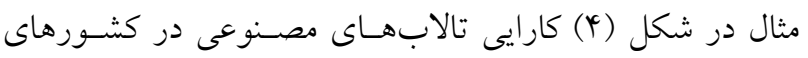

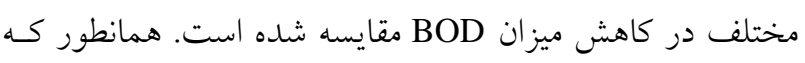

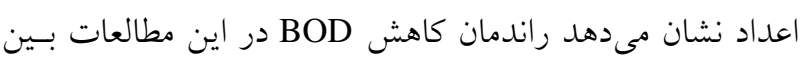
هم تا هو درصد متغير است. از طرف ديخر نتايج نشان مىدهد كه كارايى تالابها در ماهداى

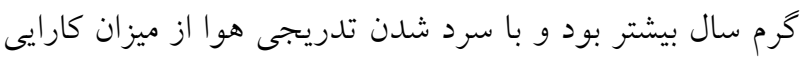

(جدول r) كارايى تالاب لوئى از نظر قابل قبول كـردن كيفيـت

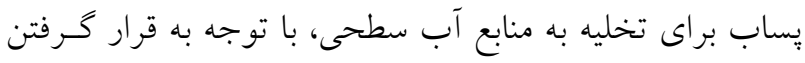

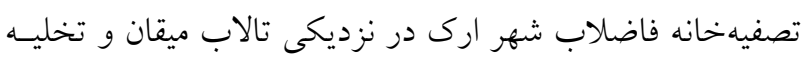

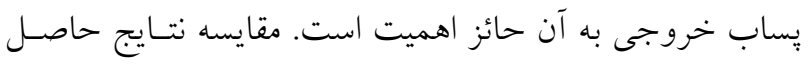

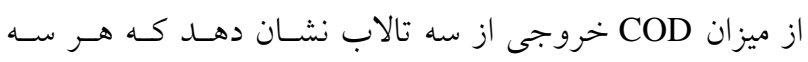
تالاب پِاب خروجى را به حد استاندارد پِاب مـورد اسـتفاده

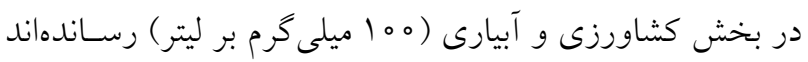

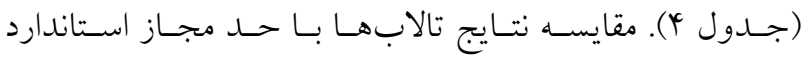

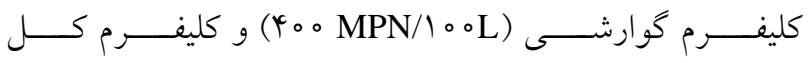

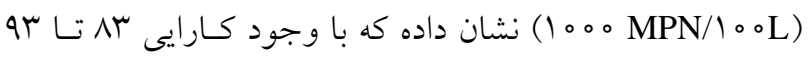
درصدى تالابهاى مورد مطالعه در كاهش بار آلودخى ميكروبى باديى

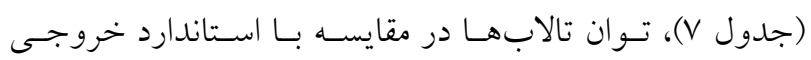

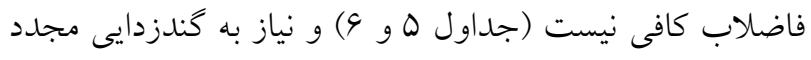

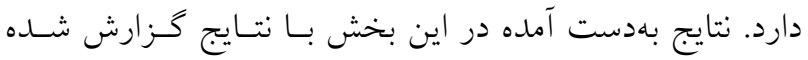

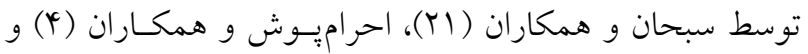
استات و همكاران (YY) همخوان است. مقايسه كارايى تالابهاى مصنوعى با همديخر نشان مىدهد

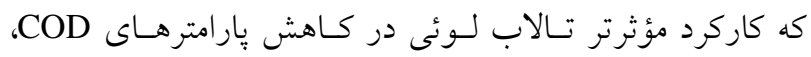
FC و FC ، TC مر مقايسه با تالاب نى و تالاب شاهد (بدون كياه) است (جدول V). با اين وجود اختلاف معنى دارى بين سه كروه

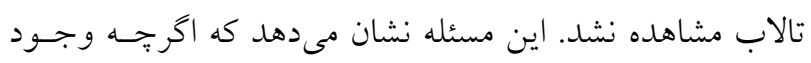

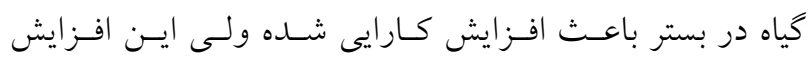

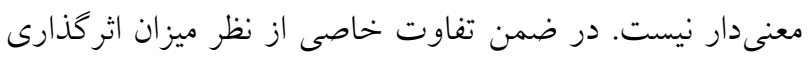

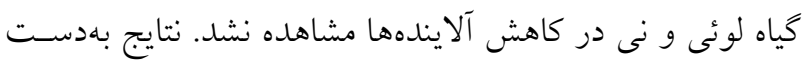

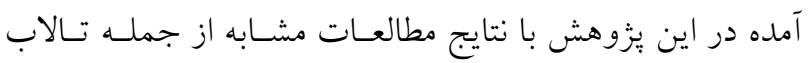


جذابتر، امروزه بسيار مورد توجه قرار گرفته است. اسـتفاده از اين تكنولوزى، در شرايط آبوهوايى متفاوت مورد توجه قـرار كرفته و براى توصيه آن بـراى هـــ منطقـهاى، نيـاز بـه بررسىى شرايط مختلف آبوهـوايى، گياهشناسى و بررسىى متغيرهـاى

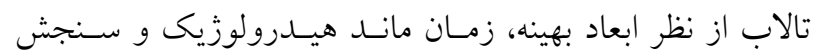
كارايى آن است. نتايج ايـن يـزَوهش نشـان داد كـه تالابهــاى مصنوعى از كارايى بالايى در كاهش آلايندههاى يساب مثل بـار

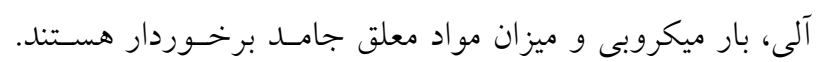
اخر جِه وجود گياهان در تالاب باعـث افـزايش كـارايى آنهـا در تصفيه يساب شده ولى ميزان آن معنى دار نيست. با ايسن وجــود، بيشترين بازدهى توسط گياه لوئى حاصل شده است. مىتوان بـا اقداماتى نظير افرايش زمان ماند و هــوادهى مصـنوعى، توانـايى تالابهاى مصنوعى در كاهش آلايندهاى بِاب را افزايش داد.

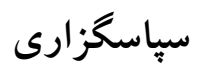

اين بزوهش با حمايتهاى مالى شركت آب و فاضـلاب اسـتان مركزى و در محل تصفيهخانه فاضلاب شـهـ اراى انجـام شـده است. از تمامى افرادى كه در انجـام ايسن بـرزوهش همكــارى و

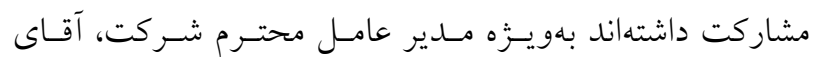

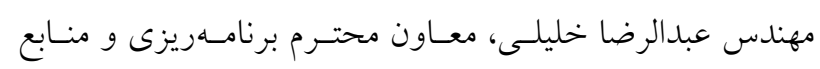
انسانى شركت، جناب آقاى مهندس حسين اميرى، ناظر پـروزه، آقاى مهندس هادى رئيسى و همكاران يروزه آقاى دكتر مسـود طاهريون و آقاى مهندس ابوالفضل رفيعىيور تشكر مى شود.
آنها در حذف بار آلى يسـاب كاسـته مىشـود. بيشـترين ميـزان درصد حذف در تالابهـا در فصـل تابسـتان و كمتـرين ميـزان حذف نيز در فصل زمستان رخ داده اسـت (شـكلهاى Y و س). اين موضـوع در مطالعـات متعـددى خـزارش شــده (N و I|) و راهحل هاى مختلفى از جمله افزايش هوادهى در تالاب، افزايش عمق تـالاب بـه بـيش از •ه سـانتى متر و اسـتفاده از فيلترهـاى

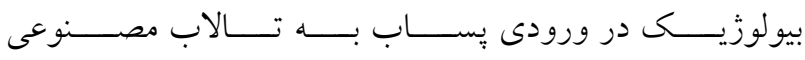

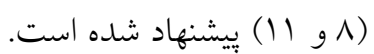

در زمينه يارامترهـاى سـاختارى مـؤثر بــر رانــدمان تالابهــاى

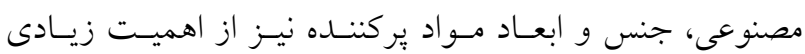
برخوردار است. شن درشت و با جنس آهكى و يـا بيوجــار از كارايى بيشترى در حذف آلاينـدهاى يسـاب برخوردارنــ (9) استفاده از شن شكسته بهجاى شن رودخانه بهدليل داشتن سطح تماس بيشتر با يساب، مىتواند دليل عدم تفاوت معنىدار ميـان

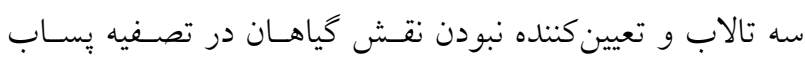

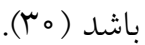
در اين مطالعه جنس و ابعاد شن خركننده تالاب و زمان ماند يساب در تالاب بهدليل محدوديتهاى بـزّوهش مـورد مطالعـه قرار نخرفت. از اينرو در يزوهشهـاى بعـدى، بررسـى بيشـتر عناصر ساختارى تالاب توصيه مىشود. تتيجه كيرى اسـتفاده از تالابهــاى مصـنوعى در تصـفيه پِسـاب بــدليـل

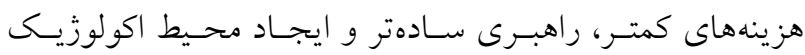

\section{منابع مورد استفاده}

1. Brisson, J and F. Chazarenc. 2009. Maximizing pollutant removal in constructed wetlands: should we pay more attention to macrophyte species selection?. Science of the Total Environment 407(13): 3923-3930.

2. Carty, A., M. Scholz, K. Heal, F. Gouriveau and A. Mustafa. 2008. The universal design, operation and maintenance guidelines for farm constructed wetlands (FCW) in temperate climates. Bioresource Technology 99(15): 67806792.

3. Ceschin, S., V. Sgambato, N. T. W. Ellwood and V. Zuccarello. 2019. Phytoremediation performance of Lemna communities in a constructed wetland system for wastewater treatment. Environmental and Experimental Botany 162: 67-71.

4. Ehrampoush, M. H., D. Hossein Shahi, A. Ebrahimi, M. T. Ghaneian, M. H. Lotfi, S. V. Ghelmani, A. Salehi Vaziri, S. H. Ayatollahi and P. Talebi. 2013. Evaluation of the efficiency of sub-surface constructed wetland methods in 
wastewater treatment in Yazd city in 2011. The Journal of Toloo-e-behdasht (In Farsi) 12(1): 33-43.

5. Eslami, H., S. V. Ghelmani, A. Salehi Vaziri, D. Hosseinshahi, S. Ghaleaskari, P. Talebi Hemmatabadi and T. Merajimoghadam. 2016. Comparing the efficiency of stabilization ponds and subsurface constructed wetland in domestic sewage treatment in city of Yazd. Journal of Water and Wastewater; Ab va Fazilab (In Farsi). 26(6): 100106.

6. Federation, W. E. and American Public Health Association. 2005. Standard Methods for the Examination of Water and Wastewater. American Public Health Association (APHA): Washington, DC, USA.

7. Haghshenas-Adarmanabadi, A., M. Heidarpour and S. Tarkesh-Esfahani. 2016. Study of the efficiency of hybrid subsurface constructed wetlands in reducing the organic loading of municipal wastewater treatment plants using various aquatic plants. Journal of Water and Soil Science (In Farsi). 20(77):111-126.

8. Jenssen, P. D., T. Mæhlum, T. Krogstad and L. Vråle. 2005. High performance constructed wetlands for cold climates. Journal of Environmental Science and Health 40(6-7): 1343-1353.

9. Kargar bideh, R., M. Doosti and M. Sayyadi. 2014. The use of horizontal subsurface flow constructed wetland for nitrogen components removal in cold and dry climate: a case study of Birjand, Iran. Journal of Water and Wastewater; Ab va Fazilab (In Farsi). 25(3): 38-47.

10. Kivaisi, A. K. 2001. The potential for constructed wetlands for wastewater treatment and reuse in developing countries: a review. Ecological Engineering 16(4): 545-560.

11. Mæhlum, T. and P. Stålnacke.1999. Removal efficiency of three cold-climate constructed wetlands treating domestic wastewater: effects of temperature, seasons, loading rates and input concentrations. Water Science and Technology 40(3): 273-281.

12. Matamoros, V. and V. Salvadó. 2012. Evaluation of the seasonal performance of a water reclamation pondconstructed wetland system for removing emerging contaminants. Chemosphere 86(2): 111-117.

13. Molleda, P., I. Blanco, G. Ansola and E. De Luis. 2008. Removal of wastewater pathogen indicators in a constructed wetland in Leon, Spain. Ecological Engineering 33(3-4): 252-257.

14. Okhravi, S., S. Eslamian and N. Fathianpour. 2018. Modeling of the effect of inflow distribution on internal hydraulic behavior of horizontal subsurface flow constructed wetland. Journal of Water and Wastewater; Ab va Fazilab (In Farsi). 29(4): 145-156.

15. Rahmani sani, A., N. Mehrdadi, A. Azimi and A. Torabian. 2009. Performance of the subsurface flow wetland in batch flow for municipal wastewater treatment. Journal of Water and Wastewater; Ab va Fazilab (In Farsi). 20(2): 32-40.

16. Saeed, T., I. Haque and T. Khan. 2019. Organic matter and nutrients removal in hybrid constructed wetlands: Influence of saturation. Chemical Engineering Journal 371: 154-165.

17. Salari, H., A. Hassani, M. Borghei, A. Yazdanbakhsh and H. Rezaei. 2012. Investigation of performance wetland in removal $\mathrm{n}$ and $\mathrm{p}$ in wastewater treatment (case study: Morad Tapeh). Journal of Water and Wastewater; Ab va Fazilab (In Farsi) 23(3): 40-47.

18. Schot, P. P. and M. J. Wassen. 1993. Calcium concentrations in wetland groundwater in relation to water sources and soil conditions in the recharge area. Journal of Hydrology141: 197-217.

19. Schröder, P., J. Navarro-Aviñó, H. Azaizeh, A. G. Goldhirsh, S. DiGregorio, T. Komives, G. Langergraber, A. Lenz, E. Maestri, A. R. Memon and A. Ranalli. 2007. Using phytoremediation technologies to upgrade waste water treatment in Europe. Environmental Science and Pollution Research-International 14(7): 490-497.

20. Shutes, R. B. E. 2001. Artificial wetlands and water quality improvement. Environment International 26(5-6): 441447.

21. Sobhan, S., S. Ayatollahi, M. Ehteshami, D. H. Shahi, S. V. Ghelmani, A. S. Vaziri and P. Talebi. 2012. The Efficiency of Typha Latifolia in subsurface flow constructed wetland for wastewater treatment. Health Develop Journal (In Farsi) 1(4): 265-270.

22. Stott, R., E. May and D. D. Mara. 2003. Parasite removal by natural wastewater treatment systems: performance of waste stabilization ponds and constructed wetlands. Water Science and Technology 48(2): 97-104.

23. Tang, X., S. Huang, M. Scholz and J. Li. 2009. Nutrient removal in pilot-scale constructed wetlands treating eutrophic river water: assessment of plants, intermittent artificial aeration and polyhedron hollow polypropylene balls. Water, Air, and Soil Pollution 197.1-4: 61.

24. Tashauee, H. R., M. Mahdavi, F. Karakani, S. V. Ghelmani and H. Ataifar. 2012. Application of horizontal subsurface flow constructed wetland for treatment of wastewater in foreign countries and Iran. Health System Research (In Farsi) 7(6): 672-683.

25. Toze, S. 2006. Water reuse and health risks—real vs. perceived. Desalination 187(1-3): 41-51.

26. Vymazal, J. 2010. Constructed wetlands for wastewater treatment: five decades of experience. Environmental Science and Technology 45(1): 61-69.

27. Yang, Q., Z. H. Chen, J. G. Zhao and B. Gu. 2007. Contaminant removal of domestic wastewater by constructed 
wetlands: effects of plants species. Journal of Integrative Plant Biology 49(4): 437-446.

28. Yousefi, Z., S. Hoseini, R. A. Mohamadpur Tahamtan and M. A. Zazouli. 2013. Performance evaluation of artificial wetland subsurface with horizontal flow in wastewater treatment. Journal of Mazandaran University of Medical Sciences (In Farsi) 23(99): 12-25.

29. Zhang, D., R. M. Gersberg and T. S. Keat. 2009. Constructed wetlands in China. Ecological Engineering 35(10): 1367-1378.

30. Zhao, Z., J. Chang, W. Han, M. Wang, D. Ma, Y. Du and Y. Ge. 2016. Effects of plant diversity and sand particle size on methane emission and nitrogen removal in microcosms of constructed wetlands. Ecological Engineering 95: 390-398. 


\title{
The Use of Sub- Surface Constructed Wetlands for Wastewater Treatment in Cold Arid Climate
}

\author{
A. Lotfi $^{1^{*}}$ and M. Mamaghninejad ${ }^{2}$
}

(Received: December 29-2018 ; May 21-2019)

\begin{abstract}
Constructed wetland as a purification system plays an important role in water and wastewater treatment and so many research studies have been conducted to examine their efficiency for wastewater treatment. The aim of this study was to evaluate the efficiency of constructed wetland for Arak wastewater treatment plant. In this research, the efficiency of three horizontal subsurface constructed wetlands built with $3 * 12$ meters in dimensions and 1 meter in depth was examined. In these constructed wetlands, two plants including Common reed (Phragmites australis) and Cattails (Typha latifolia) were planted and one unit was left unplanted. TSS, COD, BOD and TC parameters were measured in the 2 week samples and the results were analyzed by SPSS and Excel. The results showed that the type of vegetation had no significant influence on the organic matter removal in the subsurface constructed wetlands; however, the removal efficiencies in the planted constructed wetlands were more than those in the unplanted control one. The TSS, COD, BOD, FC and TC removal efficiency in the constructed wetlands changes was $79 \%, 60.7 \%, 45.6 \%, 86.1 \%$ and $90.1 \%$, respectively, for Common reed wetland and $77 \%, 61.4 \%, 59.8 \%$, 92.4\% and $93.1 \%$, respectively, for Cattails wetland; thee were $69 \%, 44.5 \%, 43 \%, 83.6 \%$ and $88.8 \%$ for the unplanted wetland, respectively. The results of this research also showed that the organic matter removal was dependent on the influent organics nature and biodegradability. The organic concentration in the wetland effluents met the Iranian regulation limits for different reuse applications, showing the constructed wetland could be a suitable technology for wastewater treatment in Iran.
\end{abstract}

Keywords: Urban wastewater, Constructed wetland, Wastewater treatment, Common red, Cattail

1. Department of Environment, Isfahan University of Technology, Isfahan, Iran

2. Improving Efficiency and Research Office, Markazi Province Water and Wastewater Company, Iran

*: Corresponding author: lotfi@iut.ac.ir 